\title{
Resistin in Preterm and Term Newborns: Relation to Anthropometry, Leptin, and Insulin
}

\author{
PAK-CHENG NG, CHEUK H. LEE, CHRISTOPHER W.K. LAM, IRIS H.S. CHAN, \\ ERIC WONG, AND TAI F. FOK
}

\author{
Department of Pediatrics [P.-C.N., C.H.L., T.F.F.], Department of Chemical Pathology [C.W.K.L., \\ I.H.S.C.], and Center of Epidemiology and Biostatistics [E.W.], Prince of Wales Hospital, The Chinese \\ University of Hong Kong, Shatin, N.T., Hong Kong
} \begin{abstract}
This study aimed to investigate 1) the plasma resistin con-
centration at birth, 2) the relationship of resistin with leptin and insulin, and 3) the association of resistin with anthropometric indexes in newborn infants. Blood samples for hormonal assay were obtained from preterm and term newborns within the first $2 \mathrm{~h}$ of life and before milk feeding or energy intake. Although these infants required blood sampling for clinical reasons, all were proved to be noninfected. Plasma resistin was significantly higher in term than in preterm infants. It was also significantly correlated with serum leptin, and both hormones were significantly associated with gestational age and anthropometric indexes. Infants who were born vaginally were found to have significantly higher plasma resistin levels compared with those who were born by cesarean section. In the multivariate forward
\end{abstract}

stepwise regression models, resistin was found to be significantly associated with the mode of delivery and gestational age or birth weight. The association among resistin, leptin, and anthropometric indexes suggested that both hormones might be gestation related. A high circulating resistin level at term gestation could be advantageous to the infant by promoting hepatic glucose production and preventing hypoglycemia after birth. Infants who were born vaginally had significantly higher plasma resistin levels, suggesting that this hormone might also be associated with stress or inflammation induced by the birth process. (Pediatr Res 58: 725-730, 2005)

\section{NPY, neuropeptide Y \\ Abbreviation}

newborns demonstrates that resistin is significantly suppressed in infants of mothers with insulin-dependent diabetes (9). The results from these $(8,9)$ and other studies in newborns $(10-13)$ highlight the important issue that these newly discovered metabolic hormones may play a crucial role in controlling fetal energy homeostasis and affecting deposition of adipose tissue in utero. To date, there are very few data on resistin in newborn infants. The interaction of resistin with other metabolic hormones such as leptin or insulin and its relationship with anthropometric indexes have not been systematically evaluated. This study, therefore, was undertaken to investigate 1) the plasma resistin concentration at birth; 2) the relationship between resistin and other metabolic hormones, including leptin and insulin; and 3) the association of resistin with anthropometric indexes in preterm $(<37 \mathrm{wk}$ gestation) and term $(37-42$ wk gestation) infants. The results may provide important information concerning the activity of resistin in human newborns and the understanding of these metabolic hormones in regulating body weight and composition in utero.

\section{METHODS}

Study population. A total of 80 preterm and term newborn infants who were admitted to the neonatal unit at the Prince of Wales Hospital, Hong Kong,
Correspondence: Professor Pak- Cheng Ng, M.D., FRCPCH., Department of Pediatrics, Level 6, Clinical Sciences Building, Prince of Wales Hospital, Shatin, N.T., Hong Kong; e-mail: pakcheungng@cuhk.edu.hk.

This project was supported by the research fund of the Department of Pediatrics, The Chinese University of Hong Kong.

DOI: 10.1203/01.PDR.0000180556.76864.9A 
were prospectively recruited during a $24-$ mo period. The neonatal unit has a very low threshold for performing sepsis screening in newborns. Enrolled term (37-42 wk gestation; $n=40$ ) and preterm infants (31-36 wk gestation; $n=$ 40 ) were newborns with increased risk for perinatal infection, such as unstable body temperature, tachypnea, or apnea, but were subsequently proved to be noninfected with normal chest radiographs, sterile blood, cerebrospinal fluid (a routine procedure in the sepsis screening protocol), urine, and surface (ear, nose, throat, and umbilicus) cultures and consistently normal serial serum $\mathrm{C}$ reactive protein concentrations $(<10 \mathrm{mg} / \mathrm{L})$. Of the term infant group one, one, three, eight, 10, and 17 infants subsequently received a diagnosis of polycythemia, laryngomalacia, pethidine-induced apnea, desaturation or apnea with unknown cause, unstable temperature, and transient tachypnea of the newborn, respectively. In addition, it has been the policy of the neonatal unit to routinely admit preterm infants with gestational age $<35 \mathrm{wk}$ and those whose birth weight $<2200 \mathrm{~g}$ for clinical assessment and monitoring. The majority of preterm infants had blood taken because of reasons associated with prematurity. The gestational age of an infant was assessed by the mother's last menstrual period and/or early ultrasound dating, and preterm infants were further cross-checked with the new Ballard Score examination (14) after birth. Infants with 1) chromosomal abnormalities, 2) major or lethal congenital malformations, and 3) proven histologic chorioamnionitis (preterm infants) and perinatal infection (preterm and term infants) and 4) those whose mother had pregestational or gestational diabetes or received hormonal therapy such as thyroxine during pregnancy or inhaled and systemic corticosteroids immediately before delivery were excluded.

Blood samples. All blood samples were collected within the first $2 \mathrm{~h}$ of life and before milk feeding or i.v. dextrose infusion. The blood collection was scheduled to coincide with the clinical blood sampling procedure to minimize any unnecessary disturbance to the infants. Venous blood was collected into 1 ) a prechilled plain bottle for serum leptin and insulin measurements, 2) a prechilled EDTA bottle that contained aprotinin (Sigma Chemical Co.-Aldrich Corp., St. Louis, MO; final concentration of 0.6 trypsin inhibitor unit $/ \mathrm{mL}$ ) for plasma resistin measurements, and 3) a fluoride bottle for plasma glucose measurements. The blood samples were immediately immersed in ice and transported to the laboratory for centrifugation at $3500 \mathrm{rpm}$ for $10 \mathrm{~min}$ at $4^{\circ} \mathrm{C}$, and the resulting plasma or serum was stored at $-70^{\circ} \mathrm{C}$ until analysis.

Hormone assays. Plasma resistin and serum leptin were measured by ELISA (Phoenix Pharmaceuticals Inc., Belmont, CA; and Diagnostic Systems Laboratories, Webster, TX, respectively). Serum insulin was measured by microparticle immunoassay (IMx analyzer; Abbott Laboratories, Abbott Park, IL) and glucose by the hexokinase method (Hitachi 917 analyzer; Roche Diagnostics Corp., Indianapolis, IN). The sensitivity and the intraassay coefficient of variation of resistin, leptin, insulin, and glucose were $0.82 \mathrm{ng} / \mathrm{mL}$ and $8.7 \%$ at $16.2 \mathrm{ng} / \mathrm{mL}, 0.05 \mathrm{ng} / \mathrm{mL}$ and $3.5 \%$ at $2.2 \mathrm{ng} / \mathrm{mL}, 1.0 \mu \mathrm{U} / \mathrm{mL}$ and $5.6 \%$ at $5.3 \mu \mathrm{U} / \mathrm{mL}$, and $2.0 \mathrm{mg} / \mathrm{dL}$ and $1.59 \%$ at $90 \mathrm{mg} / \mathrm{dL}$, respectively.

Data collection. The clinical and anthropometric data are summarized in Table 1. Birth weight was measured immediately after birth using a digital scale in the labor room and other anthropometric measurements, including body length and triceps and subscapular skinfold thickness were measured by a Harpenden infantometer and a skinfold caliper using the standard methods (9). Ethical approval of the study was obtained from the Clinical Research Ethical Committee of The Chinese University of Hong Kong. Informed parental consent was obtained for each patient before commencement of the test.

Statistical analysis. The clinical data, anthropometric indexes, and hormone concentrations were expressed as median and interquartile range. The MannWhitney $U$ test was used to compare these parameters among preterm and term infants and also between the sexes. The $\chi^{2}$ test was used to assess the categorical data. The Spearman's correlation coefficient was used to evaluate the interrelationship 1) between different metabolic hormones and 2) between metabolic hormones and clinical or anthropometric indexes. Statistically significant clinical and anthropometric parameters associated with metabolic hormones were further subjected to multivariate forward stepwise regression analysis. Logarithmic (Ln) transformation of plasma resistin concentration was required because the data were not normally distributed. Statistical tests were performed using SPSS for Windows (Release 11.5; SPSS Inc., Chicago, IL). The level of significance was set at 5\% in all comparisons.

\section{RESULTS}

Overall analysis. Table 1 summarizes the clinical characteristics and anthropometric indexes of preterm and term newborns. The term newborns had been used in our previous study and represented infants of the "normal" patient group (9). All new Ballard Scores of preterm infants corresponded with the
Table 1. A comparison of the clinical characteristics and anthropometric indexes between term and preterm newborns

\begin{tabular}{|c|c|c|}
\hline & $\begin{array}{l}\text { Term newborns } \\
\quad(\mathrm{n}=40)\end{array}$ & $\begin{array}{l}\text { Preterm newborns } \\
\qquad(\mathrm{n}=40)\end{array}$ \\
\hline Gestational age (weeks)** & $39.9(38.5-40.6)$ & $33.7(32.1-34.3)$ \\
\hline Birth weight $(\mathrm{g})^{* *}$ & $3318(2991-3590)$ & $1811(1644-2060)$ \\
\hline Male:female (n) & $20(50 \%): 20(50 \%)$ & $17(42 \%): 23(58 \%)$ \\
\hline \multicolumn{3}{|l|}{ Apgar scores: } \\
\hline$-1 \min *$ & $9(9-9)$ & $8(7-9)$ \\
\hline$-5 \min ^{*}$ & $10(9-10)$ & $9(9-10)$ \\
\hline \multicolumn{3}{|l|}{ Mode of delivery:** } \\
\hline - Cesarean section & $7(18 \%)$ & $21(52 \%)$ \\
\hline —vaginal & $33(82 \%)$ & $19(48 \%)$ \\
\hline \multicolumn{3}{|l|}{ Arterial cord blood: } \\
\hline$-\mathrm{pH}$ & $7.26(7.21-7.30)$ & $7.29(7.24-7.31)$ \\
\hline $\begin{array}{l}\text {-base deficit } \\
\mathrm{o}(\mathrm{mmol} / \mathrm{L})\end{array}$ & $-2.8(-5.6--1.6)$ & $-3.4(-4.9--1.8)$ \\
\hline Length $(\mathrm{cm})^{* *}$ & $48.8(47.7-50.3)$ & $42.5(40.8-43.9)$ \\
\hline BMI $\left(\mathrm{kg} / \mathrm{m}^{2}\right)^{* *}$ & $13.7(13.1-14.3)$ & $10.3(9.5-10.9)$ \\
\hline $\begin{array}{l}\text { Tricep skinfold thickness } \\
(\mathrm{mm})^{* *}\end{array}$ & $4.7(4.1-5.5)$ & $3.1(3.0-3.6)$ \\
\hline $\begin{array}{l}\text { Subscapular skinfold } \\
\text { thickness }(\mathrm{mm})^{* *}\end{array}$ & $4.8(4.1-5.3)$ & $3.3(2.8-3.6)$ \\
\hline
\end{tabular}

Results are median (interquartile range) or number (\%)

$* \mathrm{p}<0.02, * * \mathrm{p}<0.001$

gestational age assessment by early ultrasound and/or mother's date. Of 40 preterm patients, two, five, and 33 newborns were infants whose mother had antepartum hemorrhage, preeclampsia, and spontaneous onset of preterm labor, respectively. As expected, the anthropometric indexes were significantly greater in term than in preterm newborns (Table 1). Table 2 shows the comparison of hormone concentrations between the groups. Plasma resistin and serum leptin concentrations were significantly higher in term than in preterm infants $(p<0.0001$ for both resistin and leptin; Table 2). In contrast, there was no significant difference in serum insulin concentrations between the groups.

The correlation between resistin and gestational age, anthropometric indexes, and other metabolic hormones is summarized in Table 3. Plasma resistin was significantly correlated with serum leptin $(r=0.42, p<0.0001)$ but was not significantly associated with serum insulin $(r=-0.05, p=0.66)$. In addition, both plasma resistin and serum leptin were signifi-

Table 2. A comparison of the metabolic hormones between term and preterm newborns

\begin{tabular}{lcc}
\hline & $\begin{array}{c}\text { Term newborns } \\
(\mathrm{n}=40)\end{array}$ & $\begin{array}{c}\text { Preterm newborns } \\
(\mathrm{n}=40)\end{array}$ \\
\hline Resistin $(\mathrm{ng} / \mathrm{mL}) * *$ & $12.1(7.8-17.7)$ & $5.2(3.4-12.7)$ \\
Leptin $(\mathrm{ng} / \mathrm{mL}) * *$ & $3.0(2.1-4.0)$ & $0.7(0.2-1.1)$ \\
Insulin $(\mu \mathrm{U} / \mathrm{mL})$ & $3.5(1.8-5.3)$ & $4.9(2.2-8.5)$ \\
Glucose $(\mathrm{mg} / \mathrm{dL}) *$ & $66.7(55.9-77.5)$ & $81.0(61.3-99.1)$
\end{tabular}

Results are median (interquartile range)

$* \mathrm{p}<0.01, * * \mathrm{p}<0.0001$

Resistin conversion factor: nanograms per milliliter $\div 6.063=$ nanomoles per liter

Leptin conversion factor: nanograms per milliliter $\div 16=$ nanomoles per liter Insulin conversion factor: microunits per milliliter $\times 7.175=$ picomoles per liter

Glucose conversion factor: milligrams per deciliter $\times 0.0555=$ millimoles per liter 
Table 3. Correlation between resistin and gestational age, anthropometric indexes and other metabolic hormones of newborns

\begin{tabular}{|c|c|c|c|c|c|c|c|}
\hline \multicolumn{2}{|c|}{ Parameters } & & & \multicolumn{4}{|c|}{ Sex } \\
\hline \multirow[t]{8}{*}{ Resistin } & Gestational age & 0.29 & $0.009 *$ & 0.26 & 0.09 & 0.40 & $0.01 *$ \\
\hline & Birth weight & 0.28 & $0.01 *$ & 0.19 & 0.23 & 0.45 & $0.005^{*}$ \\
\hline & Length & 0.33 & $0.003 *$ & 0.24 & 0.12 & 0.53 & $0.001 *$ \\
\hline & Triceps & 0.21 & 0.08 & 0.18 & 0.27 & 0.26 & 0.13 \\
\hline & Subscapular & 0.13 & 0.28 & 0.04 & 0.83 & 0.21 & 0.23 \\
\hline & Leptin & 0.42 & $<0.0001 *$ & 0.32 & $0.04 *$ & 0.52 & $0.001 *$ \\
\hline & Insulin & -0.06 & 0.62 & -0.17 & 0.29 & 0.09 & 0.62 \\
\hline & Glucose & -0.11 & 0.36 & -0.07 & 0.66 & -0.22 & 0.20 \\
\hline
\end{tabular}

* statistically significant

cantly associated with gestational age $(r=0.29-0.60, p<$ 0.009) and anthropometric indexes, including birth weight, body length, and body mass index $(r=0.26-0.75, p<0.02)$. The graphic relationship between $(\mathrm{Ln})$ plasma resistin and gestational age and body weight is represented in Fig. 1.

In the subgroup analysis, infants who were born vaginally had significantly higher plasma resistin levels compared with those who were born by cesarean section [median (interquartile range): $12.8 \mathrm{ng} / \mathrm{mL}(7.0-17.9)$ versus $4.9 \mathrm{ng} / \mathrm{mL}$ (3.3-8.5); $p$ $<0.001$, respectively]. This phenomenon was also observed when term and preterm groups were analyzed separately [vaginal versus cesarean section: $13.7 \mathrm{ng} / \mathrm{mL}(8.8-19.0)$ versus 7.7 $\mathrm{ng} / \mathrm{mL}$ (7.5-10.3), $p=0.05$ for term infants; and $8.2 \mathrm{ng} / \mathrm{mL}$ (4.3-15.1) versus $3.8 \mathrm{ng} / \mathrm{mL}$ (3.1-7.6), $p=0.01$ for preterm infants, respectively]. None of the other metabolic hormones was affected by the mode of delivery. Furthermore, plasma resistin and serum leptin concentrations were not significantly different between preterm infants who were born to mothers with preeclampsia or antepartum hemorrhage and other preterm infants in the same group.

Male versus female infants. The data were further analyzed by dividing into female and male infants. There were no significant differences in clinical characteristics, anthropometric indexes, and hormonal concentrations between the sexes. In the female group, there were significant correlations between plasma resistin and serum leptin and plasma glucose (Table 3). In the male group, plasma resistin was significantly correlated with gestational age, anthropometric indexes, and serum leptin (Table 3).

Multivariate analysis. Statistically significant clinical and anthropometric parameters, including gestational age, birth weight, body length, body mass index, Apgar scores, mode of delivery, and sex, were subjected to multivariate forward stepwise regression models using ( $\mathrm{Ln})$ plasma resistin concentration as the dependent variable. The mode of delivery $(p<$ $0.01)$ and gestational age $(p<0.001)$ or birth weight $(p<$ $0.001)$ were significantly correlated with (Ln) plasma resistin. Female sex was also significantly correlated with (Ln) plasma resistin in the birth weight model $(p=0.03)$ and marginally correlated with the hormone in the gestational age model ( $p=$ 0.07; Table 4).
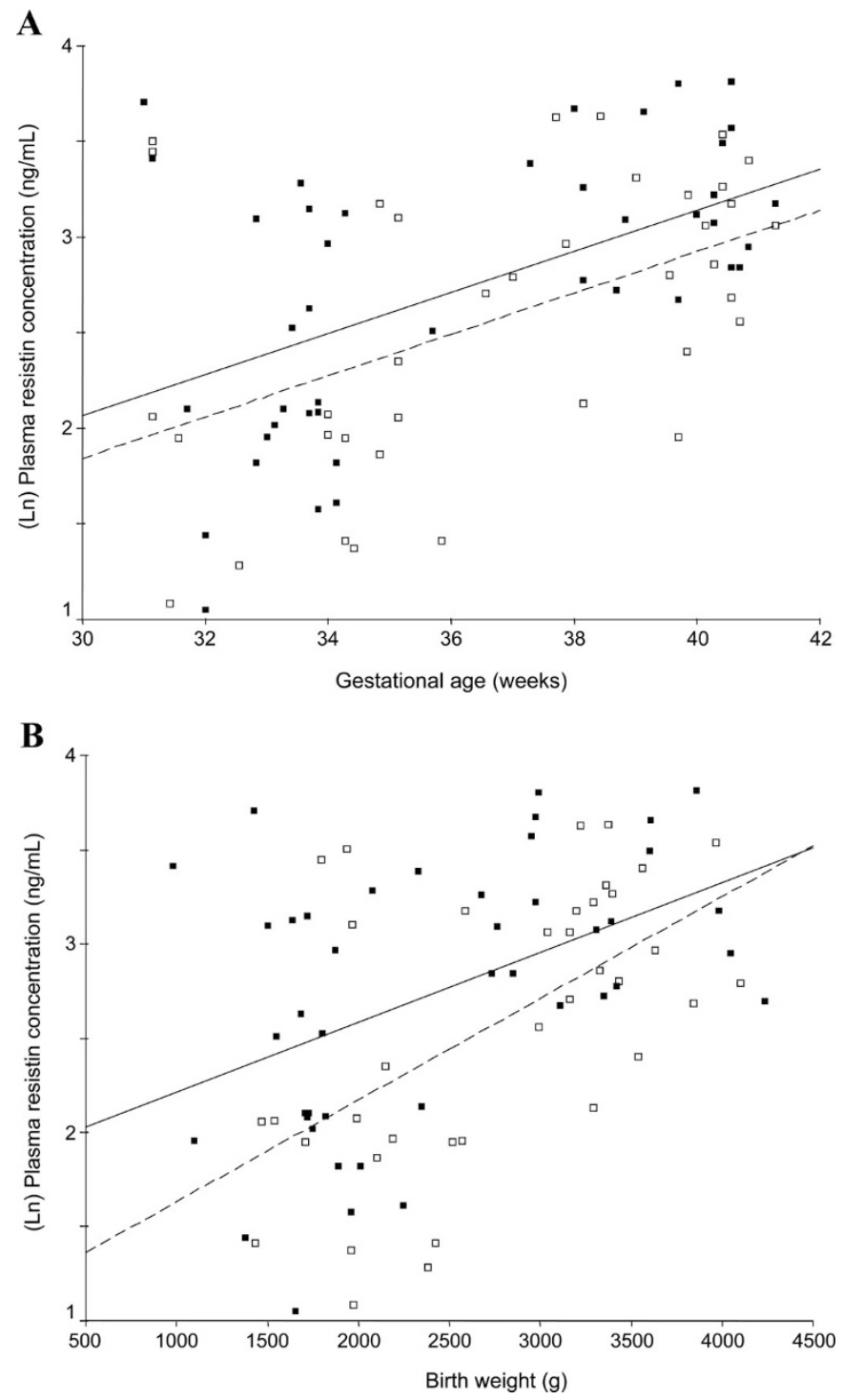

Figure 1. Scatterplots showing the relationship between $(\mathrm{Ln})$ plasma resistin concentration and gestational age [female $\left(\boldsymbol{\square}\right.$, solid line; $R^{2}=27.9 \%, p<$ $0.001)$; male $\left(\square\right.$, dashed line, $\left.\left.R^{2}=23.3 \%, p=0.002\right) A\right]$ and birth weight [female ( $\square$, solid line, $\left.R^{2}=21.0 \%, p=0.002\right)$; male $\left(\square\right.$, dashed line, $R^{2}=$ $31.3 \%, p<0.001) B]$. 
Table 4. Multivariate forward stepwise regression models showing the association between (Ln) plasma resistin concentration and other parameters

\begin{tabular}{|c|c|c|c|c|c|c|}
\hline & \multicolumn{3}{|c|}{ Birth weight model } & \multicolumn{3}{|c|}{ Gestational age model } \\
\hline & $\begin{array}{r}\text { Regression } \\
\text { coefficient }\end{array}$ & $95 \% \mathrm{CI}$ & $\mathrm{p}$ value & $\begin{array}{r}\text { Regression } \\
\text { coefficient }\end{array}$ & $95 \% \mathrm{CI}$ & $\mathrm{p}$ value \\
\hline Sex (female) & 0.33 & 0.05 to 0.60 & 0.03 & 0.26 & -0.02 to 0.53 & 0.07 \\
\hline $\begin{array}{l}\text { Mode of delivery } \\
\quad \text { (Cesarean section) }\end{array}$ & -0.39 & -0.69 to -0.01 & 0.01 & -0.40 & -0.69 to -0.11 & 0.008 \\
\hline Birth weight (OR) & 0.00038 & 0.00021 to 0.00550 & $<0.001$ & N/A & N/A & N/A \\
\hline Gestational age & N/A & N/A & N/A & 0.01 & 0.05 to 0.14 & $<0.001$ \\
\hline
\end{tabular}

Notes: $R^{2}$ is $32.3 \%$ for the birth weight model

$R^{2}$ is $33.5 \%$ for the gestational age model

Gestational age and birth weight cannot be put into the same model because of multi-collinearity problem. The correlation between the 2 parameters is $r=$ $0.82, \mathrm{p}<0.0001$

There are overall no significant interactions between sex and birth weight $(\mathrm{p}=0.27)$ or sex and gestational age $(\mathrm{p}=0.40)$

CI, confidence interval

N/A, Not applicable

\section{DISCUSSION}

Resistin is a novel adipocyte-secreted hormone that has been proposed to link obesity with diabetes $(1,2,5)$. Its physiologic role in humans remains controversial (15-18), and very little is known concerning the potential function of resistin in the pediatric population, especially in newborn infants. This study, therefore, was designed to investigate the interaction between resistin and metabolic hormones or anthropometric parameters in both preterm and term newborns. Importantly, infants with histologic chorioamnionitis or proven perinatal infection and those whose mother received dexamethasone before delivery were excluded, because inflammation and a high glucocorticoid state or the use of corticosteroids can modulate body proinflammatory cytokines and may affect the circulating levels of the metabolic hormones (19-22). The study was also designed to investigate the plasma resistin concentration soon after birth and before milk feeding or calorie intake. Although our patients required blood taking for clinical reasons, none was proved to be infected. We recognized that these infants could not be strictly considered as "ideal" normal subjects. It was not ethical, however, to perform the blood test in newborns who otherwise did not require venipuncture. In addition, our recent study (9) with the same cohort of term infants demonstrated that these infants could function adequately as control infants in the clinical setting.

Plasma resistin was detectable in all studied infants at birth, and its levels in preterm and term newborns are summarized in Table 2. Plasma resistin concentrations in newborns were comparable to the circulating resistin levels in adults described by Lee et al. (23) [mean ( $\pm \mathrm{SD}): 9.3 \mathrm{ng} / \mathrm{mL}( \pm 7.7)$ in middle-aged women and $4.5 \mathrm{ng} / \mathrm{mL}( \pm 1.9)$ in young subjects] but were lower than the levels reported by Yannakoulia et al. (24) [mean ( $\pm \mathrm{SD}): 16.9 \mathrm{ng} / \mathrm{mL}( \pm 5.4)$ in female subjects and $14.0 \mathrm{ng} / \mathrm{mL}( \pm 7.2)$ in male subjects]. More important, our findings revealed that both plasma resistin and serum leptin concentrations were significantly higher in term than in preterm newborns. There was also a significant and positive association between resistin and leptin, and both hormones were correlated with gestational age and anthropometric indexes at birth, suggesting that these metabolic hormones could be gestation related and might play an important role in regulating energy metabolism and adiposity in utero. Although such a relationship with leptin has been previously reported by us $(8,25)$ and other investigators $(10-13,26)$, the link between resistin and gestational age or anthropometric indexes at birth, to our knowledge, has not been reported. In addition, our results in newborns were in accordance with the findings on healthy adults without severe inflammatory diseases in whom a correlation was also observed between leptin and resistin in serum (18) and that circulating resistin levels were higher in obese than in lean individuals (27). However, conflicting data have since been presented regarding the aforementioned relationship in adults (23). The inconsistencies between studies might have been related to variation in sample size, different methods of resistin measurements, and fluctuation of blood resistin concentrations among different categories of patients $(23,24,27)$. In the current study, we tried to minimize some of these factors by recruiting a relatively large number of infants and, more important, having very stringent entry criteria for enrollment.

Two major metabolic roles have been proposed for resistin. First, resistin antagonizes the action of insulin and impairs glucose homeostasis (1). The net effects are 1) increase in glucose production that is, at least in part, mediated by the AMP-activated protein kinase pathway, resulting in increase in expression of hepatic gluconeogenic enzymes (28), and 2) decrease in the ability of skeletal muscle and adipose tissue to uptake glucose in response to insulin (29). Second, resistin possesses an anti-adipogenic property and inhibits the proliferation of 3T3-L1 adipocytes (2). In addition, circulating resistin levels have been shown to be elevated in both genetic and diet-induced rodent models of diabetes and obesity (1). Thus, the current evidence supports the hypothesis that resistin may induce hyperglycemia (28) or contributes to insulin resistance (1) and inhibits adipogenesis (2). In this study, the progressive increase in plasma resistin concentration with gestational age and during a period (latter half of third trimester) when there is rapid accumulation of fetal fat mass $(8,10)$ can be advantageous to the newborn. A high circulating resistin level at term may prevent hypoglycemia at birth by facilitating hepatic 
glucose production. Furthermore, an effective regulation of adipogenesis by negative feedback signaling from adipocytes can limit excessive proliferation and accumulation of fat tissue in the infant. Such an adaptive response in nutritional and energy regulation raises the possibility that resistin together with other metabolic hormones may play a critical role in ensuring the survival of the newborn by providing adequate substrate-glucose-for CNS utilization and avoiding the production of an excessively fat or large fetus that may adversely affect the process of normal childbirth. Although our hypothesis might explain to some extent the neonatal physiologic requirement at birth, the results could be interpreted differently. The lack of significant correlation between resistin and insulin or glucose might suggest that resistin was not involved directly in the regulation of metabolism or adipose tissue in utero. The increase in plasma resistin concentrations with advancing gestational age might merely reflect a larger adipose tissue mass that produces a greater quantity of the hormone toward the late stages of pregnancy. However, the latter assumption is not entirely logical or satisfactory, as it would be difficult to explain 1) why resistin was not functionally active in utero and 2 ) the finding of our recent study (9) that showed convincingly a potent suppressive effect of insulin on resistin in newborn infants of mothers with insulin-dependent diabetes. In addition, the current study was never intended or designed to trace the origin of resistin in newborn infants. A recent study demonstrated the expression of resistin gene in trophoblastic cells of the placenta (30). Moreover, the expression of resistin gene in term placental tissue was more prominent compared with the expression found in the chorionic villi in the first trimester (30). Whether the pattern of increase in plasma resistin concentration with advancing gestational age in newborns is in any way related to the up-regulation of placental resistin expression in late pregnancy will require further investigation.

The signaling pathways of resistin have yet to be identified and mapped out properly. Recent studies in immunohistochemistry reveal that brain cells of the arcuate nucleus contain neuropeptide Y (NPY), which is known to be associated with increase in food intake (31). In contrast, leptin inhibits neurons that contain this chemical and reduces feeding (32). This immunohistochemical technique also demonstrates the presence of resistin protein in the arcuate nucleus and pituitary gland, and reverse transcription-PCR detects resistin mRNA in the hypothalamic-pituitary system (33). Moreover, intracerebroventricular administration of NPY to mice increases resistin gene expression in white adipose tissues, suggesting that the regulation of resistin may be controlled centrally and related to NPY (34). Although the exact signaling circuit that mediates resistin actions has not been fully elucidated, the significant association between resistin and leptin demonstrated in the current study and the relation of these two metabolic hormones with NPY raise the possibility that resistin and leptin may act centrally and influence each other in related metabolic pathways.

Our findings also suggest that the mode of delivery in addition to gestational age and birth weight was an independent factor affecting plasma resistin concentrations at birth. The circulating resistin levels were significantly higher in infants who were delivered vaginally than by cesarean section. Furthermore, this phenomenon was consistently observed in both preterm and term infants when their results were analyzed separately. This was an unexpected finding and thus far has not been reported in the literature. This observation bore close resemblance to the stress hormone cortisol, which was also found to be significantly elevated in infants who were born vaginally (35). Resistin has been implicated to have a potential role in mediating inflammatory response (5) and being influenced by proinflammatory stimuli or cytokines such as lipopolysaccharide or tumor necrosis factor- $\alpha(4,36)$. Although the exact mechanism of this phenomenon cannot be fully elucidated by the current study, we speculate that the elevated resistin level may be related to stress or inflammation induced by vaginal delivery.

\section{CONCLUSION}

In summary, our findings indicate that plasma resistin and serum leptin concentrations are significantly higher in term than in preterm newborns. A high circulating resistin level at term may assist the infant in maintaining an adequate blood glucose concentration and preventing hypoglycemia. The significant relationship between resistin and leptin and their association with gestational age and anthropometric indexes suggest that both metabolic hormones are gestation related and may play an important role in modulating energy homeostasis and regulating growth in utero. Furthermore, we speculate that the elevated plasma resistin concentration in infants who were delivered vaginally might have been related to stress or inflammation induced by the birth process.

\section{REFERENCES}

1. Steppan CM, Bailey ST, Bhat S, Brown EJ, Banerjee RR, Wright CM, Patel HR, Ahima RS, Lazar MA 2001 The hormone resistin links obesity to diabetes. Nature 409:307-312

2. Kim KH, Lee K, Moon YS, Sul HS 2001 A cysteine-rich adipose tissue-specific secretary factor inhibits adipocyte differentiation. J Biol Chem 276:11252-11256

3. Zhang Y, Proenca R, Maffei M, Barone M, Leopold L, Friedman JM 1994 Positional cloning of the mouse obese gene and its human homologue. Nature 372:425-432

4. Steppan CM, Lazar MA 2002 Resistin and obesity-associated insulin resistance. Trends Endocrinol Metab 13:18-23

5. Holcomb IN, Kabakoff RC, Chan B, Baker TW, Gurney A, Henzel W, Nelson C, Lowman HB, Wright BD, Skelton NJ, Frantz GD, Tumas DB, Peale FV Jr, Shelton DL, Hebert CC 2000 FIZZ1, a novel cystein-rich secreted protein associated with pulmonary inflammation, defines a new gene family. EMBO J 19:4046-4055

6. Cummings DE, Purnell JQ, Frayo RS, Schmidova K, Wisse BE, Weigle DS 2001 A preprandial rise in plasma ghrelin levels suggests a role in meal initiation in humans. Diabetes 50:1714-1719

7. Shintani M, Ogawa Y, Ebihara K, Aizawa-Abe M, Miyanaga F, Takaya K, Hayashi T, Inoue G, Hosoda K, Kojima M, Kangawi K, Nakao K 2001 Ghrelin, an endogenous growth hormone secretagogue, is a novel orexigenic peptide that antagonizes leptin action through the activation of hypothalamic neuropeptide Y/Y1 receptor pathway. Diabetes 50:227-232

8. Ng PC, Lam CW, Lee CH, Wong GW, Fok TF, Chan IH, Ma KC, Wong E 2000 Leptin and metabolic hormones in preterm newborns. Arch Dis Child Fetal Neonatal Ed 83:F198-F202

9. Ng PC, Lee CH, Lam CW, Wong E, Chan IH, Fok TF 2004 Plasma ghrelin and resistin concentrations are suppressed in infants of insulin-dependent diabetic mothers. J Clin Endocrinol Metab 89:5563-5568

10. Jaquet D, Leger J, Levy-Marchal C, Oury JF, Czernichow P 1998 Ontogeny of leptin in human fetuses and newborns: effect of intrauterine growth retardation on serum leptin concentrations. J Clin Endocrinol Metab 83:1243-1246

11. Cetin I, Morpurgo PS, Radaelli T, Taricco E, Cortelazzi D, Bellotti M, Pardi G, Beck-Peccoz P 2000 Fetal plasma leptin concentrations: relationship with different intrauterine growth patterns from 19 weeks to term. Pediatr Res 48:646-651

12. Shekhawat PS, Garland JS, Shivpuri C, Mick GJ, Sasidharan P, Pelz CJ, McCormick KL 1998 Neonatal cord blood leptin: its relationship to birth weight, body mass index, maternal diabetes, and steroids. Pediatr Res 43:338-343 
13. Varvarigou A, Mantzoros CS, Beratis NG 1999 Cord blood leptin concentrations in relation to intrauterine growth. Clin Endocrinol (Oxf) 50:177-183

14. Ballard JL, Khoury JC, Wedig K, Wang L, Eilers-Walsman BL, Lipp R 1991 New Ballard Score, expanded to include extremely premature infants. J Pediatr 119:417423

15. Nagaev I, Smith U 2001 Insulin resistance and type 2 diabetes are not related to resistin expression in human fat cells or skeletal muscle. Biochem Biophys Res Commun 285:561-564

16. Savage DB, Sewter CP, Klenk ES, Segal DG, Vidal-Puig A, Considine RV, O'Rahilly S 2001 Resistin/FIZZ3 expression in relation to obesity and peroxisome proliferatoractivated receptor-gamma action in humans. Diabetes 50:2199-2202

17. McTernan CL, McTernan PG, Harte AL, Levick PL, Barnett AH, Kumar S 2002 Resistin, central obesity, and type 2 diabetes. Lancet 359:46-47

18. Meier U, Gressner AM 2004 Endocrine regulation of energy metabolism: review of pathobiochemical and clinical chemical aspects of leptin, ghrelin, adiponectin, and resistin. Clin Chem 50:1511-1525

19. Faggioni R, Fantuzzi G, Fuller J, Dinarello CA, Feingold KR, Grunfeld C 1998 IL-1 $\beta$ mediates leptin induction during inflammation. Am J Physiol 274:R204-R208

20. Ng PC, Lam CW, Lee CH, Fok TF, Chan IH, Ma KC, Wong E 2002 Changes in serum leptin concentration after corticosteroid treatment in preterm infants. Acta Paediatr 91:684-690

21. Kaser S, Kaser A, Sandhofer A, Ebenbichler CF, Tilg H, Patsch JR 2003 Resistin messenger-RNA expression is increased by proinflammatory cytokines in vitro. Biochem Biophys Res Commun 309:286-290

22. Krsek M, Silha JV, Jezkova J, Hana V, Marek J, Weiss V, Stepan JJ, Murphy LJ 2004 Adipokine levels in Cushing's syndrome; elevated resistin levels in female patients with Cushing's syndrome. Clin Endocrinol (Oxf) 60:350-357

23. Lee JH, Chan JL, Yiannakouris N, Kontogianni M, Estrada E, Seip R, Orlova C, Mantzoros CS 2003 Circulating resistin levels are not associated with obesity or insulin resistance in humans and are not regulated by fasting or leptin administration: cross-sectional and international studies in normal, insulin-resistant, and diabetic subjects. J Clin Endocrinol Metab 88:4848-4856

24. Yannakoulia M, Yiannakouris N, Blüher S, Matalas AL, Klimis-Zacas D, Mantzoro CS 2003 Body fat mass and macronutrient intake in relation to circulating soluble leptin receptor, free leptin index, adiponectin, and resistin concentrations in healthy humans. J Clin Endocrinol Metab 88:1730-1736
25. Ng PC, Lam CW, Lee CH, Wong GW, Fok TF, Wong E, Ma KC, Chan IH 2000 Leptin and metabolic hormones in infants of diabetic mothers. Arch Dis Child Fetal Neonatal Ed 83:F193-F197

26. Harigaya A, Nagashima K, Nako Y, Morikawa A 1997 Relationship between concentration of serum leptin and fetal growth. J Clin Endocrinol Metab 82:32813284

27. Degawa-Yamauchi M, Bovenkerk JE, Juliar BE, Watson W, Kerr K, Jones R, Zhu Q, Considine RV 2003 Serum resistin (FIZZ3) protein is increased in obese humans. $\mathrm{J}$ Clin Endocrinol Metab 88:5452-5455

28. Banerjee RR, Rangwala SM, Shapiro JS, Rich AS, Rhoades B, Qi Y, Wang J, Rajala MW, Pocai A, Scherer PE, Steppan CM, Ahima RS, Obici S, Rossetti L, Lazar MA 2004 Regulation of fasted blood glucose by resistin. Science 303:1195-1198

29. Rajala MW, Obici S, Scherer PE, Rossetti L 2003 Adipose-derived resistin and gut-derived resistin-like molecule-beta selectively impair insulin action on glucose production. J Clin Invest 111:225-230

30. Yura S, Sagawa N, Itoh H, Kakui K, Nuamah MA, Korita D, Takemura M, Fujii S 2003 Resistin is expressed in the human placenta. J Clin Endocrinol Metab 88:13941397

31. Håkansson ML, Brown H, Ghilardi N, Skøda RC, Meister B 1998 Leptin receptor immunoreactivity in chemically defined target neurons of the hypothalamus. J Neurosci 18:559-572

32. Elmquist JK, Maratos-Flier E, Saper CB, Flier JS 1998 Unraveling the central nervous system pathways underlying responses to leptin. Nat Neurosci 1:445-450

33. Morash BA, Wilkinson D, Ur E, Wilkinson M 2002 Resistin expression and regulation in mouse pituitary. FEBS Lett 526:26-30

34. Yuzuriha H, Inui A, Goto K, Asakawa A, Fujimiya M, Kasuga M 2003 Intracerebroventricular administration of NPY stimulates resistin gene expression in mice. Int J Mol Med 11:675-676

35. Kase NG, Reyniak JV, Bergh PA 1991 Endocrinology in pregnancy. In: Cherry SH, Merkatz IR (eds) Complications of Pregnancy: Medical, Surgical, Gynecologic, Psychosocial, and Perinatal. 4th Ed. Williams \& Wilkins, Baltimore, pp 916-939

36. Lu SC, Shieh WY, Chen CY, Hsu SC, Chen HL 2002 Lipopolysaccharide increases resistin gene expression in vivo and in vitro. FEBS Lett 530:158-162 